Левицька С. О., д.е.н., професор, Полюхович М. Д., аспірант (Національний університет водного господарства та природокористування, м. Рівне)

\title{
ОЦІНКА ІННОВАЦІЙНОГО РОЗВИТКУ ПРОМИСЛОВИХ ПІДПРИЕМСТВ УКРАЇНИ
}

У статті досліджено сучасний стан інноваційного розвитку підприємств України. Проаналізовано динаміку основних показників інноваційної діяльності. Відображено структуру джерел фінансування інноваційної діяльності в Україні. Обґрунтовано причини низької інноваційної активності вітчизняних підприємств.

Ключові слова: інновації, інноваційна діяльність, активізація інноваційної діяльності, джерела фінансування.

Вступ. Інноваційний розвиток економіки України $€$ одним 3 пріоритетів національних економічних досліджень. Інноваційна діяльність - необхідна складова процесу забезпечення успішного, довготривалого та стійкого функціонування вітчизняних підприємств, одна з фундаментальних складових ефективної стратегії, важливий інструмент забезпечення їхніх конкурентних переваг. Проблема активізації інноваційної діяльності вітчизняних підприємств з проголошенням Україною євроінтеграційного курсу набуває особливої актуальності, адже без підвищення інноваційної активності підприємств неможливо досягти підвищення ефективності та конкурентоспроможності вітчизняного виробництва. Інновації $€$ стимулом для конкурентоспроможного розвитку підприємств, формують лідируючі позиції та можливість виходу на світові ринки. Виходячи з цього, виникає необхідність проаналізувати показники та спрямованість інноваційної політики підприємств України і з'ясувати, чому стримується розвиток інноваційної діяльності вітчизняних підприємств.

Аналіз останніх досліджень. Оцінкою сучасного стану інноваційної активності України займається багато вітчизняних та зарубіжних економістів, серед яких Г.О. Андрощук, Ю.З. Драчук, Н.Ю. Жаровська, Л.О. Іванець, О.А. Клич, Т.В. Романова, С.М. Січко, В.В. Шарко та інших. Однак досліджувані категорії не $є$ статичними, вони постійно змінюються, тому вимагають регулярного аналізу для виявлення основних тенденцій на етапах формування концептуальних основ постіндустріальної економіки. 
Методика досліджень. Методологічною основою дослідження $\epsilon$ наукові праці вітчизняних і зарубіжних учених з проблеми оцінки інноваційної діяльності. У процесі дослідження використовувалася сукупність методів: розрахунковий - у визначенні показників інноваційної діяльності в Україні; графічний - для аналізу й наочного відображення отриманих результатів; монографічний - для визначення причин низької інноваційної активності вітчизняних підприємств.

Постановка завдання. Метою даного дослідження $\epsilon$ оцінка ключових показників інноваційної діяльності та інноваційної політики підприємств України, визначення основних тенденцій розвитку досліджуваних процесів.

Результати досліджень. Основою для розвитку національного виробництва $€$ досягнення конкурентоздатності підприємств як на внутрішньому, так і на зовнішньому ринках. Конкуренція зумовлює появу на ринку підприємств, що активно займаються інноваційною діяльністю. Інноваційний розвиток вітчизняної економіки залежить від державної інноваційної політики, рівня наукового і науковотехнічного потенціалу, розвитку національної інноваційної системи та інших показників.

На стан інноваційної активності в Україні впливають багато факторів, однак ми погоджуємося 3 думкою Жаровської Н.Ю. [4], яка вважає, що усі фактори можна поділити на дві групи:

- фактори зовнішнього впливу, що включають фактори ділового середовища підприємства, які не залежать від нього, мають прямий або опосередкований вплив, та визначають напрями і обмеження інноваційного розвитку;

- фактори внутрішнього впливу, що впливають на здійснення інноваційної діяльності на виробничому підприємстві, залежать від його цілей і стратегії, обсягу та якості доступних ресурсів, інноваційного потенціалу, ефективності системи управління та інших.

Для того, щоб визначити основні тенденції розвитку інноваційної діяльності, варто дослідити загальні показники інноваційної діяльності на макрорівні.

Основні показники, що характеризують зміст та динаміку інноваційної діяльності, представлено в табл. 1. 
Таблиця 1

Основні показники інноваційної діяльності в Україні

за 2010-2016 роки

\begin{tabular}{|c|c|c|c|c|c|c|c|}
\hline \multirow{2}{*}{ Показники } & \multicolumn{7}{|c|}{ Роки } \\
\hline & 2010 & 2011 & 2012 & 2013 & 2014 & 2015 & 2016 \\
\hline $\begin{array}{l}\text { Кількість інно- } \\
\text { ваційно- } \\
\text { активних підп- } \\
\text { риємств, оди- } \\
\text { ниць }\end{array}$ & 1462 & 1679 & 1758 & 1715 & 1609 & 824 & 834 \\
\hline $\begin{array}{l}\text { Кількість підп- } \\
\text { риємств, що } \\
\text { впроваджува- } \\
\text { ли інновації, } \\
\text { одиниць }\end{array}$ & 1217 & 1327 & 1371 & 1312 & 1208 & 723 & 735 \\
\hline $\begin{array}{l}\text { Загальний об- } \\
\text { сяг фінансу- } \\
\text { вання іннова- } \\
\text { ційної діяльно- } \\
\text { сті, млн грн }\end{array}$ & 8045,5 & 14333,9 & 11480,6 & 9562,6 & 7695,9 & 13813,72 & 23229, \\
\hline $\begin{array}{l}\text { Обсяг реалізо- } \\
\text { ваної іннова- } \\
\text { ційної продук- } \\
\text { ції в промисло- } \\
\text { вості, млн грн }\end{array}$ & 33697, & 642386,7 & 36157,7 & 35862,7 & 25669,0 & 023050,1 & $x$ \\
\hline $\begin{array}{l}\text { Обсяг реалізо- } \\
\text { ваної іннова- } \\
\text { ційної продук- } \\
\text { ції за межі Ук- } \\
\text { раїни, млн грн }\end{array}$ & 13713 & 12630,6 & 13354,9 & 16053,4 & 7500,0 & 10843,8 & $x$ \\
\hline
\end{tabular}

Джерело: складено автором за даними [5]

У 2016 році інноваційною діяльністю у промисловості займалися 834 підприємства, що на 628 підприємств менше за показник 2010 року. Кількість підприємств, що впроваджували інновації теж зменшилася з 1217 од. в 2010 році до 735 од. в 2016 році.

Зменшення темпів розвитку інноваційної діяльності в Україні переважно зумовлені недостатністю фінансування. Не менш важливими чинниками зазначеного $є$ глибока соціально-економічна криза, падіння курсу національної валюти, недостатній рівень підготовки наукових кадрів, недосконалість матеріально-технічної бази тощо. 
3 табл. 1 також видно, що обсяг реалізованої інноваційної продукції в промисловості невпинно, починаючи з 2011 року, зменшувався на 6229 млн грн (на 14,7\%) в 2012 році, на 295 млн грн (на 0,8\%) в 2013 році, на 10193,7 млн грн (на $28,4 \%$ ) в 2014 році та на $2618,9 \mathrm{Mлн}$ грн (на $10,2 \%$ ) в 2015 році.

Питому вагу інноваційно активних підприємств наведено на рис. 1. Зауважимо, що відповідно до методологічних положень Державної служби статистики України, інноваційно активними підприємствами вважаються підприємства, що в період обстеження займалися діяльністю, пов'язаною зі створенням інновацій, незалежно від того, чи призвела така діяльність до реального впровадження інновацій [2].

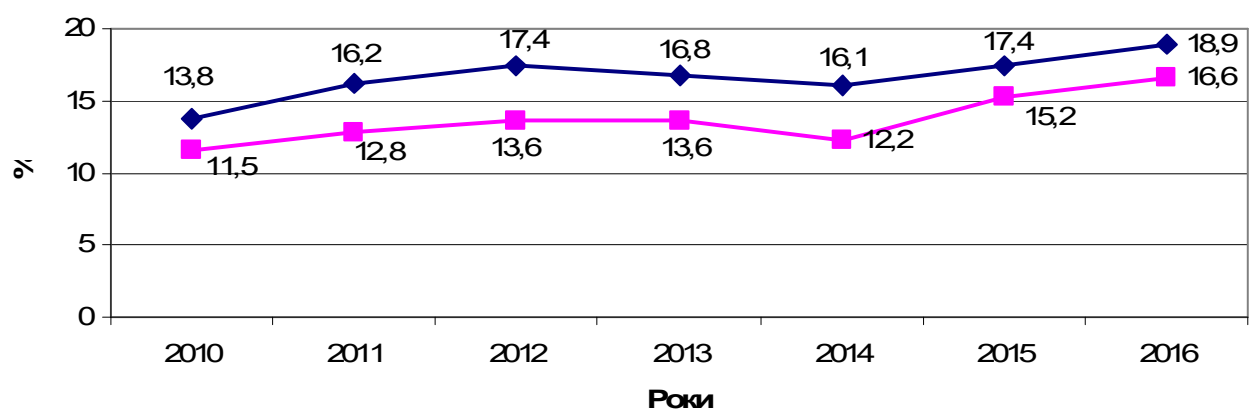

- - ПИтома вага гідгриемств, що займагися інноваціями

Питома вага підгриемств, що впроваджуваги інноваціі

Рис. 1. Динаміка питомої ваги підприємств, що займалися впровадженням інновацій та впроваджували інновації протягом 2000-2016 років

Джерело: складено автором за даними [5]

Протягом 2000-2016 років частка підприємств, що займалися інноваціями, мала незначні зміни. Поступово спостерігається певне збільшення частки підприємств, що займалися впровадженням інновацій - з 13,8\% в 2010 році до 18,9\% в 2016 році. Для порівняння: у США, Японії, Німеччині й Франції частка інноваційних підприємств становить 70-80\% від їх загальної кількості [6].

Стрімкий інноваційний розвиток на сьогоднішній день демонструють також азіатські країни. Так, на Китай, Японію та Південну Корею в 2016 році припадало понад 40\% усіх глобальних інвестицій [6].

3 рис. 1 також видно, що в загальній структурі частка промислових підприємств, що впроваджували інновації залишається невеликою, незважаючи на позитивну динаміку протягом досліджувано- 
го періоду: за 2010-2016 роки цей показник складав в середньому $13,6 \%$.

Розподіл підприємств залежно від типу впроваджуваних інновацій наведений на рис. 2.

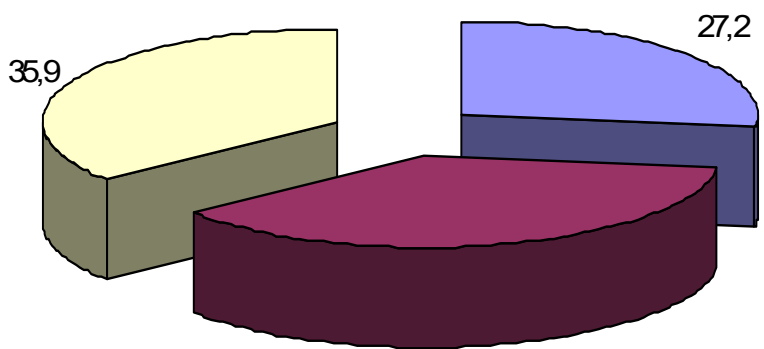

36,9

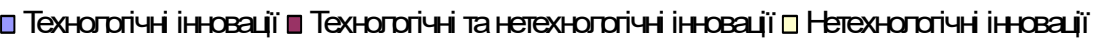

Рис. 2. Розподіл підприємств залежно від типу впроваджуваних інновацій в Україні за 2014-2016 роки, \% Джерело: складено автором за даними [3]

3 рис. 2 видно, що питомі частки підприємств, що запроваджували різні типи інновацій були практично рівними (по третині на кожну групу підприємств): із загальної кількості інноваційних підприємств 27,2\% займалися технологічними інноваціями (продуктові та/або процесові), 35,9\% - нетехнологічними (організаційними та/або маркетинговими), 36,9\% - технологічними та нетехнологічними інноваціями.

За досліджуваний період найвищий рівень інноваційної активності спостерігався серед підприємств у сфері інформації та телекомунікації (22,1\%), переробної промисловості (22,0\%) [3]. Більшість інноваційно активних підприємств поряд з технологічними запроваджували також нетехнологічні інновації - розробку та впровадження нових або значно вдосконалених процесів, що не належать до технологічних інновацій. До цієї групи входять маркетингові та організаційні інновації [2]. 
Динаміка впровадження інновацій на промислових підприємствах протягом 2010-2016 років

\begin{tabular}{|c|c|c|c|c|c|}
\hline Роки & $\begin{array}{c}\text { Впроваджено } \\
\text { нових техноло- } \\
\text { гічних процесів, } \\
\text { од. }\end{array}$ & $\begin{array}{c}\text { у т.ч. мало- } \\
\text { відходні, ре-- } \\
\text { сурсозбері- } \\
\text { гаючі }\end{array}$ & $\begin{array}{c}\text { Освоєно вироб- } \\
\text { ництво іннова- } \\
\text { ційних видів } \\
\text { подукції, най- } \\
\text { менувань }\end{array}$ & $\begin{array}{c}\text { з них } \\
\text { нові ви- } \\
\text { ди тех- } \\
\text { ніки }\end{array}$ & $\begin{array}{c}\text { Питома вага } \\
\text { реалізованої } \\
\text { інноваційної } \\
\text { продукції в } \\
\text { обсязі про- } \\
\text { мислової, \% }\end{array}$ \\
\hline 2010 & 2043 & 479 & 2408 & 663 & 3,8 \\
\hline 2011 & 2510 & 517 & 3238 & 897 & 3,8 \\
\hline 2012 & 2188 & 554 & 3403 & 942 & 3,3 \\
\hline 2013 & 1576 & 502 & 3138 & 809 & 3,3 \\
\hline 2014 & 1743 & 447 & 3661 & 1314 & 2,5 \\
\hline 2015 & 1217 & 458 & 3136 & 966 & 1,4 \\
\hline 2016 & 3489 & 748 & 4139 & 1305 & х \\
\hline
\end{tabular}

Джерело: складено автором за даними [5]

Показник питомої ваги реалізованої продукції в обсязі промислової свідчить про низьку результативність інноваційної діяльності вітчизняних підприємств. 3 таблиці 2 видно, що частка реалізованої інноваційної продукції за досліджуваний період зменшилася з 3,8\% в 2010-2011 роках до 1,4\% в 2015 році.

Ще одна негативна тенденція стосується структури джерел фінансування інноваційної діяльності в Україні за 2010-2016 роки (табл. 3).

Представлені дані свідчать, що головним джерелом фінансування інноваційної діяльності підприємств протягом останніх років $€$ власні кошти. Так, їхня частка зросла з 59,4\% в 2010 році до 94,9\% в 2016 році. Натомість частка державних коштів протягом досліджуваного періоду не перевищувала $4,5 \%$. Відповідно, можемо констатувати, що держава відіграє, на жаль, не достатньо результативну роль у підтримці інноваційної діяльності України. Це є основною проблемою реалізації інноваційної політики на вітчизняних підприємствах.

Таблиця 3

Структура джерел фінансування інноваційної діяльності в

Україні за 2010-2016 роки

\begin{tabular}{|c|c|c|c|c|c|c|c|c|c|}
\hline \multirow[b]{2}{*}{ Роки } & \multirow[b]{2}{*}{$\begin{array}{c}\text { Загальна } \\
\text { сума ви- } \\
\text { трат, млн } \\
\text { грн }\end{array}$} & \multicolumn{8}{|c|}{ У тому числі за рахунок коштів, млн грн } \\
\hline & & 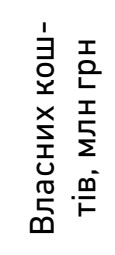 & 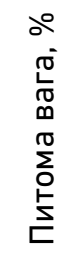 & 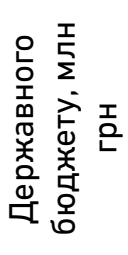 & 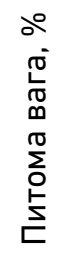 & 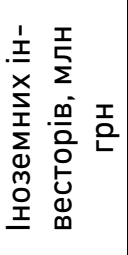 & 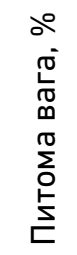 & 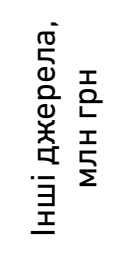 & 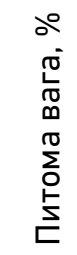 \\
\hline 2010 & 8045,5 & 4775,2 & 59,4 & 87,0 & 1,1 & 2411,4 & 30,0 & 771,9 & 9,6 \\
\hline 2011 & 14333,9 & 7585,6 & 52,9 & 149,2 & 1,0 & 56,9 & 0,4 & 6542,2 & 45,6 \\
\hline
\end{tabular}


продовження табл. 3

\begin{tabular}{|c|c|c|c|c|c|c|c|c|c|}
\hline 2012 & 11480,6 & 7335,9 & 63,9 & 224,3 & 2,0 & 994,8 & 8,7 & 2925,6 & 25,5 \\
\hline 2013 & 9562,6 & 6973,4 & 72,9 & 24,7 & 0,3 & 1253,2 & 13,1 & 1311,3 & 13,7 \\
\hline 2014 & 7695,9 & 6540,3 & 85,0 & 344,1 & 4,5 & 138,7 & 1,8 & 672,8 & 8,7 \\
\hline 2015 & 13813,7 & 13427,0 & 97,2 & 55,1 & 0,4 & 58,6 & 0,4 & 273,0 & 2,0 \\
\hline 2016 & 23229,5 & 22036,0 & 94,9 & 179,0 & 0,8 & 23,4 & 0,1 & 991,1 & 4,3 \\
\hline
\end{tabular}

Джерело: складено автором за даними [5]

Низьким залишається рівень інвестиційної привабливості інноваційного сектора і для зовнішніх інвесторів, що свідчить про несприятливий інвестиційний клімат в Україні.

Висновки. Тенденції інноваційної діяльності останніх років вказують на наявність значних проблем та низький рівень розвитку інноваційної діяльності в Україні, що, в свою чергу, негативно відображається на конкурентоздатності продукції та розвитку економіки в цілому.

Наведені висновки дозволяють стверджувати, що діяльність інноваційно-активних підприємств не досягає необхідного рівня задля переходу України на новий етап соціально-економічного розвитку - інноваційний. Спостерігається поступове зниження обсягу реалізованої продукції як в Україні, так і за ії межами, знижуються обсяги діяльності, зокрема за такими напрямами, як дослідження та розробки, освоєння нових технологічних процесів.

Серед основних проблем, що стримують інноваційну діяльність в Україні, можна виділити наступні:

- відсутня підтримка з боку держави, яка проявляється не лише в недостатності фінансування інноваційного розвитку економіки України, але й в існуванні складного нормативного забезпечення, відсутності мотиваційної інноваційної політики. В Україні діє 14 законів, понад 50 підзаконних актів, а також понад 100 правових актів відомчого характеру, які регулюють питання інноваційної діяльності підприємств. В той же час, державна фінансова підтримка та податкове стимулювання, передбачене цими актами, не застосовуються в повному обсязі;

- обмежені фінансові можливості українських підприємств, які не дозволяють купувати сучасне виробниче обладнання, фінансувати продуктові інновації та власні наукові дослідження. Проведене дослідження показали, що держава виділяє менше 1\% коштів на підтримку інноваційної політики підприємств України;

- узагальнюючи, можна стверджувати, що розвиток інноваційної діяльності забезпечує, перш за все, мобілізація всіх джерел фінансування. 
3 іншого боку, Україна володіє низкою важливих переваг: ресурсним забезпеченням, досить високим загальним рівнем освіти населення, потужною кількістю вищих навчальних закладів. Відтак, необхідним $€$ здійснення змін у політиці фінансування й кредитування інноваційних процесів на вітчизняних підприємствах.

1. Андрощук Г. О. Інноваційна діяльність в Україні: економічний механізм стимулювання : Інтелектуальна власність. 2000. № 12. С. 23-28. 2. Державна служба статистики України URL: www.ukrstat.gov.ua/ metod_polog/metod_doc/2015/369/met_st_id.zip (дата звернення : 02.10.2018). 3. Державна служба статистики України URL: http://www.ukrstat.gov.ua/express/expres_u.html (дата звернення : $01.10 .2018)$. 4. Жаровська Н. Ю. Класифікація та характеристика факторів впливу на інноваційну діяльність машинобудівних підприємств. Сталий розвиток економіки. 2015. № 3. С. 191-197. URL: http://nbuv.gov.ua/UJRN/sre 2015329 (дата звернення : 02.10.2018). 5. Наукова та інноваційна діяльність в Україні. URL: http://www.ukrstat.gov.ua/druk/publicat/kat_u/publnauka_u.htm (дата звернення : 02.10.2018). 6. Січко С. М. Інноваційний розвиток країн світу. Науковий вісник Ужгородського національного університету. Міжнародні економічні відносини та світове господарство. 2016. Вип. 7(3). С. 92-95. URL: http://nbuv.gov.ua/UJRN/Nvuumevcg_2016_7(3)_25 (дата звернення : 01.10.2018).

\section{REFERENCES :}

1. Androshchuk H. O. Innovatsiina diialnist v Ukraini: ekonomichnyi mekhanizm stymuliuvannia : Intelektualna vlasnist. 2000. № 12. S. 23-28. 2. Derzhavna sluzhba statystyky Ukrainy URL: www.ukrstat.gov.ua/ metod_polog/metod_doc/2015/369/met_st_id.zip (data zvernennia : 02.10.2018). 3. Derzhavna sluzhba statystyky Ukrainy URL: http://www.ukrstat.gov.ua/express/expres_u.html (data zvernennia : $01.10 .2018)$. 4. Zharovska N. Yu. Klasyfikatsiia ta kharakterystyka faktoriv vplyvu na innovatsiinu diialnist mashynobudivnykh pidpryiemstv. Stalyi rozvytok ekonomiky. 2015. № 3. S. 191-197. URL: http://nbuv.gov.ua/UJRN/sre_2015_3_29 (data zvernennia : 02.10.2018). 5. Naukova ta innovatsiina diialnist $v$ Ukraini. URL: http://www.ukrstat.gov.ua/druk/publicat/kat_u/publnauka_u.htm (data zvernennia : 02.10.2018). 6. Sichko S. M. Innovatsiinyi rozvytok krain svitu. Naukovyi visnyk Uzhhorodskoho natsionalnoho universytetu. Mizhnarodni ekonomichni vidnosyny ta svitove hospodarstvo. 2016. Vyp. 7(3). S. 92-95. URL: http://nbuv.gov.ua/UJRN/Nvuumevcg_2016_7(3)_25 (data zvernennia : 01.10.2018).

Рецензент: д.е.н., професор Осадча О. О. (НУВГП) 
Levytska S. O., Doctor of Economics, Professor, Poliuhovych M. D., Post-graduate Student (National University of Water and Environmental Engineering, Rivne)

\section{EVALUATION OF INNOVATIONAL DEVELOPMENT OF INDUSTRIAL ENTERPRISES OF UKRAINE}

The modern state of innovation development of enterprises of Ukraine is investigated in the article. The factors influencing the development of innovation activity of domestic enterprises were disclosed. The dynamics of innovative activity of industrial enterprises in Ukraine are analyzed. It was also considered the structure of sources of financing innovative activity in Ukraine. The sources of funding of the innovation were investigated in order to a comprehensive analysis of indicators of innovation activity, namely the share of own funds, resources that are allocated from the state budget and off-budget funds, domestic and foreign investors, credit money. The main problems hampering innovation activity in Ukraine were defined.

Keywords: innovation, innovation process, activation of innovation activity, sources of financial resources.

Левицкая С. А., А.э.н., профессор, Полюхович М. Д., аспирант (Национальный университет водного хозяйства и природопользования, г. Ровно)

\section{ОЦЕНКА ИННОВАЦИОННОГО РАЗВИТИЯ ПРОМЫШЛЕННЫХ ПРЕДПРИЯТИЙ УКРАИНЫ}

В статье исследовано современное состояние инновационного развития предприятий Украины. Проанализирована динамика инновационной деятельности промышленных предприятий Украины. Отображена структура источников финансирования инновационной деятельности в Украине. Обоснованно причины низкой инновационной активности отечественных предприятий.

Ключевые слова: инновации, инновационная деятельность, активизация инновационной деятельности, источники финансирования. 